\title{
EFFECTS OF ADDING HUMATE AND HYDRATED SODIUM CALCIUM ALUMINOSILICATE TO CONTAMIINATED CHICKEN DIETS ON AFLATOXICOSIS
}

\author{
R. A. Hassan ${ }^{1}$, W. A. Morsy ${ }^{1}$, Nadia L. Radwan ${ }^{1}$ and Y. Eid ${ }^{2}$ \\ 1- Animal Production Research Institute, Agricultural Research Center, Ministry \\ of Agriculture, Dokki, Cairo, Egypt, 2- Department of Poultry Production, Faculty \\ of Agriculture, Kafr Elsheikh University
}

\section{SUMMARY}

A total number of 360, one-day old unsexed El-Salam chicks, were divided randomly into six groups of 60 chicks each that represents 6 dietary treatments, each in 3 replicates. Chicks of treatment lreceived the basal diet without supplementation. Chicks of treatment 2 received the basal diet contaminated with 1 ppm aflatoxin $B_{1} /$ $\mathrm{kg}$ diet (AF-diet). Chicks of treatment 3, 4, 5 and 6 were fed the AF-diet supplemented with $0.1,0.25,0.40 \%$ humate or $0.50 \%$ hydrated sodium calcium aluminosilicate (HSCAS), respectively. The experimental diets were fed from 1 day old to $56^{\text {th }}$ day of age (treated period), thereafter, chicks of each group were fed the control diet without supplementation till the end of the $84^{\text {th }}$ day of age (57 - 84) as a recovery period.

The results showed that:

1-Chicks fed aflatoxin contaminated diet (AF-diet) recorded lower body weight, feed intake, lower feed conversion and higher mortality rate than the control diet at the end of the treated period.

2- Relative weights of liver, kidney, spleen and proventriculus significantly increased in birds fed aflatoxin contaminated diet (AF-diet).

3-Chicks fed diets contaminated with $1 \mathrm{ppm}$ of aflatoxin $B_{1} / \mathrm{kg}$ diet exhibited lower values of serum total protein, albumin, total lipids, cholesterol and uric acid and higher values of liver enzyme functions.

4- The digestion coefficients of nutrients were significantly decreased in aflatoxin fed group.

5-Addition of humate at levels of 0.10, 0.25 and $0.40 \%$ protected chick body weight by (60.77, 78.55 and 80.36\%), feed intake by (52.86, 63.98 and $50.00 \%$ ) and feed conversion ratio by (70.30, 89.05 and 95.30\%), respectively, against $1 \mathrm{ppm}$ AFB1 at 8 weeks of age. Addition of HSCAS protected chick body weight by (73.52\%), feed intake by (53.44\%) and feed conversion ratio (FCR) by ( $85.95 \%$ ) against 1 ppm AFB1 at 8 weeks of age A recovery period, may overcomes some toxic symptoms in chicks.

Keywords: Aflatoxin, humate, aluminosilicate, prevention, chicks

\section{INTRODUCTION}

Aspergillus species infect economically important crops and forages in the field and during storage, transportation and processing. These fungi produce aflatoxin,

Issued by The Egyptian Society of Animal Production 
which contaminate food and animal feeds worldwide, causing serious health problems and livestock production losses. Aflatoxin $\mathrm{B}_{1}\left(\mathrm{AFB}_{1}\right)$ the most toxic of the aflatoxins, is often encountered in food and animal feeds at alarming concentrations around the world (Marquardt, 1996). Unfortunately, discontinuing the feeding of aflatoxin-contaminated grain is not always practical especially when alternate feedstuffs are not readily available or affordable (Ramos et al., 1996b). Several of physical, chemical and biological techniques for mycotoxin decontamination of agricultural commodities have been used, but they have had limited success (Doyle et al., 1982).

One of the most practical approaches is the use of nonnutritive adsorbents, which bind the mycotoxins and inhibit their absorption from the gastrointestinal tract, thus minimizing the toxic effects in livestock and the carryover of these fungal metabolites into animal products (Ramos et al., 1996a). Aluminosilicates, activated charcoal, polymers, such as cholestyramine and polyvinylpyrrolidones, and yeast and yeast products have been extensively studied with promising, but with varying results (Huwig et al., 2001). For an adsorbent to successfully prevent the absorption of aflatoxins from the gastrointestinal tract, it should have a high affinity for aflatoxin resulting in the formation of a strong complex with little risk of dissociation. The adsorbent should also have a high binding capacity, to prevent saturation (Ramos and Hernandez, 1996).

Humic acid form colloid solutions, can protect the digestive tract mucosa from the effects of infectious and toxic agents. Due to their chelate structure, humic acid can bind various toxic agents, thus forming insoluble and non- resorbable complexes ( Alvarez- Puebla et al., 2004); that may be shed through the intestines ( Kuhnert et al., 1982a,b). Mechanisms of adaptive and bio- regulative qualities of humic acid and their salts are associated with their stimulating effect on immunological responses, detoxicating activity within livers and sulphydryl-disulphide balance in protein and saccharide metabolism ( Santos et al., 2004) .

Colloidal characteristics of humic acid and their salts and their ability to form chalets, can significantly modify the toxic effects of a number of xenobiotics and undesirable substances that enter the digestive tract together with feeds and water (Livens, 1991 and Herzig et al., 1994). Their strong affinity to mutagens (Cozzi et al., 1993), pesticides (Negre et al., 2001), mono aromatic and polycyclic aromatic compounds (Kollist-Sugur et al., 2001 and Nanny and Maza, 2001), heavy metals (Madronova et al., 2001), aflatoxin $\mathrm{B}_{1}$ (Rensburg et al., 2006) and microorganisms (Fein et al., 1999) was described.

The HSCAS binds AFB1 in vitro (Scheideler, 1993). Thus, the efficacy of sorbent materials as HSCAS probably lies in their ability to bind AF in the intestine, rendering the toxin unavailable for absorption (Southern et al., 1994). Ingestion of HSCAS to broilers does not improve skin pigmentation (Brake, 1987). The sorbent additives have raised questions about their effects on minerals and vitamins status, although Chung and Baker (1990) with P, Chung et al. (1990) with riboflavin and Southern et al. (1994) and Qota (2003) with Ca and P, have reported that HSCAS does not impair the nutrient utilization.

The objective of this study was to evaluate the effects of humate and HSCAS on growth performance, serum constituents and carcass characteristics in local chicks exposed to aflatoxins. 


\section{MATERIALS AND METHODS}

The present study was carried out at Sakha Animal Production Research Station, Animal Production Research Institute, Agricultural Research Center.

A total number of 360 one-day old unsexed chicks of El-Salam strain (Nicolas X Mamourah) were wing banded, weighed and randomly divided into 6 treatment groups nearly similar in average body weight. Each treatment consist of three replicates of 20 chicks each. Feed and water were provided ad libitum. Chicks were grown in brooders raised wire floors. All chicks were kept under similar managerial hygienic and environmental conditions. Chicks at one-day old were offered the six experimental diets using a basal diet. Basal diets were formulated to cover nutrient requirements (Table 1) according to Egyptian Feed Composition Table (2001). The $\mathrm{AFB}_{1}$ content of the basal diet showed very little amount of $5 \mathrm{ppb}$. Chicks were allotted on the following treatments:

(1) The basal diet without any supplement served as a control diet.

(2) Basal diet contaminated with aflatoxin $\mathrm{B}_{1}\left(\mathrm{AFB}_{1}\right)$ with rate $1 \mathrm{ppm} / \mathrm{kg} \operatorname{diet}(\mathrm{AF}-$ diet).

(3) AF-diet $+0.1 \%$ humate

(4) AF-diet $+0.25 \%$ humate.

(5) AF-diet $+0.40 \%$ humate.

(6) AF-diet $+0.50 \%$ hydrated sodium calcium aluminosilicate (HSCAS).

Table 1. Composition and calculated analysis of the basal diet fed during the experimental period

\begin{tabular}{lcc}
\hline Ingredients \% & Starter (0- 8wks) & Finisher (9-12wks) \\
\hline Yellow corn & 64.00 & 71.44 \\
Soybean meal (44\% CP) & 32.10 & 20.00 \\
Wheat bran & 00.00 & 4.69 \\
Di-calcium phosphate & 1.80 & 1.62 \\
Limestone & 1.40 & 1.60 \\
Sodium chloride & 0.30 & 0.35 \\
Vit. min. mixture (premix) ${ }^{1}$ & 0.30 & 0.30 \\
DL- Methionine & 0.10 & -- \\
Total & $\mathbf{1 0 0}$ & $\mathbf{1 0 0}$ \\
Calculated analysis & & \\
Metabolizable energy ( Kcal/Kg) & 2860 & 15.00 \\
Crude protein \% & 19.56 & 3.62 \\
Crude fiber \% & 3.65 & 3.20 \\
Crude fat \% & 2.69 & 1.06 \\
Calcium \% & 1.03 & 0.43 \\
Available phosphate \% & 0.47 & 0.79 \\
Lysine \% & 1.03 & 0.28 \\
Methionine \% & 0.41 & 0.55 \\
Met + cystine \% & 0.74 & \\
\hline Suplied per kg of diet : Vit. A, 10.000 IU; Vit. D3, 2000IU; Vit. E, 10 mg ; Vit. K3, 1 mg; \\
Vit. B1, 1 mg ; Vit. B2, 5 mg; Vit. B6, 1.5 mg ; Vit. B12, 10 mcg ; Niacin, 30 mg; \\
Pantothenic acid, 10 mg ; Folic acid , 1 mg ; Biotin, 50 mcg ; Choline, 260 mg; Copper, 4 \\
mg ; Iron, 30 mg ; Manganese, 60 mg; Zinc, 50 mg; Iodine, 1.3 mg; Selenium, 0.1 mg; \\
Cobalt, 0.1 mg & &
\end{tabular}


Aflatoxin was produced via fermentation of rice by Aspergillus parasiticus NRRL 2999 as described by Shotwell et al. (1966) and modified by West et al. (1973). Fermented rice was autoclaved, dried and ground to a fine powder, which was analyzed for its AF content by method of Nabney and Nesbitt (1965) as modified by Wiseman et al. (1967). The $\mathrm{AFB}_{1}$ in the rice powder was extracted by chloroform then incorporated into basal diet and confirmed by HPLC to provide the desired level of $1 \mathrm{mg}$.

Biofarm ${ }^{\circledR}$ Dry, totally natural humate was purchased from Farmavet International Istnbul-Turkey. Each $\mathrm{kg}$ of humate contained $160 \mathrm{mg}$ polymeric polyhydroxy acid (humic, fulvic, ulmic and humatomelanic acids), $663.3 \mathrm{SiO}_{2}$ and other minerals $(\mathrm{Mn}$, $50 \mathrm{mg}$; Zn, $60 \mathrm{mg}$; Fe, $60 \mathrm{mg}$; Cu, $5 \mathrm{mg}$; Co, $0.2 \mathrm{mg}$; I, $1 \mathrm{mg}$; Se, $0.5 \mathrm{mg}$ and Al, Na, $\mathrm{K}, \mathrm{Mg}$ and $\mathrm{P}$ in trace amounts).

Hydrated sodium calcium aluminosilicate (HSCAS) is a chemical compound that containing Silica, 64.70\%; Aluminum, 15.50\%; Iron, 1.75\%; Calcium, $1.26 \%$; Potassium, 1.80\%; Sodium, 2.55\% and Magnesium, 1.54\% and moisture $10.9 \%$, provided from Integrated World Enterprises Co. USA.

Experimental diets were fed for 8 weeks (treatment period) followed by another 4 weeks as a recovery period during which birds were offered the control diet. Parameters investigated included body weights and feed intake of the chicks (measured weekly) and mortality (daily) recorded. At the end of treatment period (8 weeks of age) and 12 weeks of age (the end of recovery period), 3 chicks from each treatment were taken randomly for carcass evaluation. Liver, kidney, spleen, heart, thymus, gizzard and proventriculus were removed and weighed. Organ weights were expressed as percentages of body weight. A total number of 36 samples from meat (as mixture of $50 \%$ breast $+50 \%$ thigh), as well as from liver tissue were collected for chemical analysis according to the official methods of AOAC (2000). Serum was collected to determine changes in the total protein (TP), albumin (Alb), cholesterol (Chol), total lipids (TL) and uric acid (UA) as well as activity of alanine aminotransferase (ALT), aspartate aminotransferase (AST) and creatine kinase (Cr). Blood constituents were determined by colorimetric methods using commercial kits supplied from Biomerieux (Poains, France). The digestion coefficients of dietary nutrients were examined using 3 birds from each treatment at the end of treatment and recovery periods. Fecal nitrogen was determined according to the method outlined by Jakobsen et al. (1960). The proximate analyses of feed and dried excreta were carried out according to AOAC (2000). Liver and meat samples were analyzed for aflatoxin content according to (AOAC, 2000) method.

\section{Protection percentage:}

For any parameter studied, to compare the anti-aflatoxic effects achieved by the different agents studied, a protection percentage was calculated as follows;

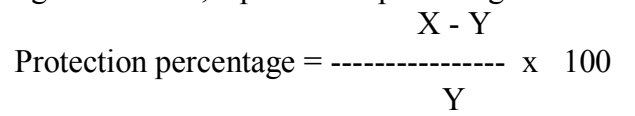

Where, $\mathrm{X}=$ change of AF- group (T2) from control (T1), and $\mathrm{Y}=$ change of any other group ( T3,------- T6) from control .

Data were subjected to one way analysis of variance using the General Linear Model of $\mathrm{SAS}^{\mathrm{R}}$ software (SAS, 1998). Before analysis, all percentages were subjected to logarithmic or arcsine values transformation $(\log 10 x+1)$ to approximate 
normal distribution. Significant differences among treatment means $(p \leq 0.05)$ were separated by Duncan's new multiple range test (Duncan, 1955).

The following model was used to study the effect of some feed additives (humate or hydrated sodium calcium aluminosilicate with aflatoxin) on parameters investigated as follows:

Where,

$$
\mathrm{Yij}=\mu+\mathrm{Ti}+\mathrm{eij}
$$

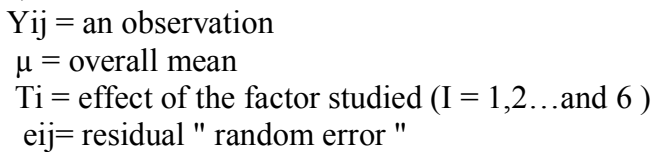

\section{RESULTS AND DISCUSSION}

\section{Growth Performance:}

Data presented in Table 2 show the effect of the experimental feed additives on body weight $(\mathrm{BW})$, feed intake (FI) and feed conversion ratio (FCR) during treatment and recovery periods, respectively. Feeding basal diet supplemented with AF significantly $(\mathrm{P}<0.05)$ reduced $\mathrm{BW}, \mathrm{FI}$ and recorded the worst FCR compared to the control group $(\mathrm{P}<0.05)$. Feeding the AF-diet decreased $\mathrm{BW}$ by $22.66 \%$, FI by $6.83 \%$ and resulted in a poorer FCR by $21.92 \%$ at 8 weeks of age (end the treatment period). Results herein are consistent with those reported by Kubena et al. (1992); Scheideler (1993) and Edrington et al. (1997) who mentioned about $6.5-38 \%$ reduction in body weight of chicks fed diet containing aflatoxin than the control diet. The reduction in feed intake and poorer feed conversion of chicks may be attributed to the harmful effect of aflatoxin on the liver as well as the negative impact of aflatoxin on the activity of enzymes involved in starch, lipids and nucleic acid digestion in broiler (Osborn and Hamilton, 1981).

The addition of humate levels especially at 0.25 and $0.40 \%$ improved BW by (23.02 and $23.56 \%)$, FI by (4.69 and $3.66 \%$ ) and FCR by (16.01 and $17.13 \%)$, respectively, compared to chicks fed AF-diet, and alleviate the adverse effect by (78.55 and $80.36 \%),(63.98$ and $50.00 \%)$ and (89.05 and $95.30 \%)$, respectively, at 8 weeks of age (end of treatment period). These results indicated that 0.25 and $0.40 \%$ humate ameliorated the adverse effects of $\mathrm{AF}$ on performance parameters (BW, FI and FCR) of local chicks. These results agree with Rensburg et al. (2006) who reported that the decrease in BW gain was diminished at $42 \mathrm{~d}$ of age by the addition of $3.5 \mathrm{~g}$ of oxihumate/ $\mathrm{kg}$ of contaminated diet with AF.

The addition of HSCAS protected BW by $73.52 \%$, FI by $53.44 \%$ and FCR by $85.95 \%$ against $1 \mathrm{ppm}$ AFB1 at 8 weeks of age. These results agree with those obtained by Kubena et al. (1990a\&b); Scheideler (1993); Hassan (2000) and Qota et al. (2005) who reported that adding 0.5\% HSCAS improved chick body weight, feed intake and feed conversion ratio compared to chicks fed AF-supplemented diet.

During recovery period, the adverse effects on chicks BW, FI and FCR for all aflatoxin groups were gradually diminished. At the end of recovery period, chicks fed AF-supplemented diet without or with humate and HSCAS consumed more feed than that of the control group. This may be due to compensatory growth after being inhibited by aflatoxicosis during treatment period (Table 2). There were insignificant differences in FCR values among the experimental treatments during recovery period 
(8-12 weeks of age). Postmortem investigation indicated that mortalities were due to aflatoxicosis during the $5^{\text {th }}$ and $8^{\text {th }}$ week of treatment period. Mortality rates averaged 2.0, 20.0, 6.6, 5.5, 5.0 and 8.0\% for control, $\mathrm{AF}-$ diet, $\mathrm{AF}+0.1 \%$ humate, $\mathrm{AF}+0.25 \%$ humate, $\mathrm{AF}+0.40$ humate and $\mathrm{AF}+0.5 \%$ HSCAS, respectively. The higher mortality rate due to aflatoxicosis was also reported by Kubena et al. (1990b); Edrington et al. (1997) and Ghazalah et al. (1995). In this respect, Rensburg et al. (2006) found that adding oxihumate decreased mortality rate compared to broiler chicks fed AFsupplemented diet. Also, Kubena et al. (1990a) found that mortality rates decreased from 30 to $10 \%$ by adding $0.5 \%$ HSCAS to aflatoxic diets. In this study, chicks consumed diet supplemented with $1 \mathrm{ppm} / \mathrm{kg} \mathrm{AFB}_{1}$ showed a significant reduction in body weight. Also, AF negatively affected feed consumption and FCR values. These adverse effects on performance of birds were noticed from the $2^{\text {nd }}$ week until the end of the treatment period which may be due to anorexia, listlessness, inhibition of protein synthesis and lipogenesis (Oguz and Kurtoglu, 2000 and Parlat et al., 2001). Impaired liver functions and utilization of protein, lipid and carbohydrate may have also affected the growth performance and general health (Miazzo et al., 2000 and Ortatatli and Oguz, 2001).

Table 2. Effect of humate levels and hydrated sodium calcium aluminosilicate (HSCAS) on growth performance of birds fed diet containing $1 \mathrm{ppm} \mathrm{AFB1/} \mathrm{kg}$ diet at the end of treatment and recovery periods

\begin{tabular}{|c|c|c|c|c|c|c|c|}
\hline Treatment & $\begin{array}{c}\text { Live body } \\
\text { weight } \\
\text { g }\end{array}$ & $\begin{array}{c}\text { Change } \\
\text { from } \\
\text { control } \\
(\%) \\
\end{array}$ & $\begin{array}{c}\text { Feed } \\
\text { intake } \\
\text { (g) }\end{array}$ & $\begin{array}{c}\text { Change } \\
\text { from } \\
\text { control } \\
(\%) \\
\end{array}$ & $\begin{array}{c}\text { Feed } \\
\text { conversion } \\
\text { (g feed/g } \\
\text { gain) }\end{array}$ & $\begin{array}{c}\text { Change } \\
\text { from } \\
\text { control } \\
(\%) \\
\end{array}$ & $\begin{array}{c}\text { Mortality } \\
(\%)\end{array}$ \\
\hline \multicolumn{8}{|c|}{ At the end of treatment period (8 wk of age) } \\
\hline Control & $750.00^{\mathrm{a}}$ & 0.00 & $2098.33^{\mathrm{a}}$ & 0.00 & $2.92^{\mathrm{c}}$ & 0.00 & 3.33 \\
\hline AF-diet & $580.00^{d}$ & -22.66 & $1955.00^{\mathrm{c}}$ & -6.83 & $3.56^{\mathrm{a}}$ & +21.92 & 20.0 \\
\hline$A F+0.1 \%$ humate & $683.33^{\mathrm{c}}$ & -8.89 & $2030.66^{\mathrm{b}}$ & -3.22 & $3.11^{\mathrm{b}}$ & +6.51 & 6.66 \\
\hline $\mathrm{AF}+0.25 \%$ humate & $713.53^{\mathrm{b}}$ & -4.86 & $2046.66^{\mathrm{b}}$ & -2.46 & $2.99^{c}$ & +2.40 & 5.00 \\
\hline $\mathrm{AF}+0.40 \%$ humate & $716.66^{\mathrm{b}}$ & -4.45 & $2026.66^{\mathrm{b}}$ & -3.42 & $2.95^{\mathrm{c}}$ & +1.03 & 5.00 \\
\hline $\mathrm{AF}+0.50 \% \mathrm{HSCAS}$ & $705.00^{\mathrm{b}}$ & -6.00 & $2031.66^{\mathrm{b}}$ & -3.18 & $3.01^{\mathrm{c}}$ & +3.08 & 8.33 \\
\hline SEM & 13.137 & - & 10.852 & - & 0.054 & - & - \\
\hline P-value & 0.0001 & - & 0.0001 & - & 0.0001 & - & - \\
\hline \multicolumn{8}{|c|}{ At the end of recovery period (12 wk of age) } \\
\hline Control & $1206.66^{\mathrm{a}}$ & 0.00 & 1582.00 & 0.00 & 3.46 & 0.00 & 1.66 \\
\hline AF-diet & $1005.00^{\mathrm{d}}$ & -16.71 & 1566.66 & -1.00 & 3.68 & +6.36 & 10.0 \\
\hline $\mathrm{AF}+0.1 \%$ humate & $1135.00^{\mathrm{c}}$ & -5.94 & 1597.66 & +1.00 & 3.54 & +2.31 & 3.33 \\
\hline $\mathrm{AF}+0.25 \%$ humate & $1166.66^{\mathrm{b}}$ & -1.68 & 1590.00 & +0.50 & 3.52 & +1.73 & 1.66 \\
\hline AF $+0.40 \%$ humate & $1173.33^{b}$ & -1.12 & 1586.00 & +0.25 & 3.48 & +0.58 & - \\
\hline $\mathrm{AF}+0.50 \% \mathrm{HSCAS}$ & $1158.33^{b c}$ & -2.38 & 1583.33 & +0.08 & 3.50 & +1.16 & 5.00 \\
\hline SEM & 15.96 & - & 4.323 & - & 0.033 & - & - \\
\hline P-value & 0.0001 & - & 0.497 & - & 0.444 & - & - \\
\hline
\end{tabular}

$\mathrm{a}, \mathrm{b}, \mathrm{c}, \mathrm{d}$ Means in the same column having different litter are significantly different $(\mathrm{P}<0.05)$

\section{Weights of Some Internal Organs:}

The effect of feed additives on alleviation of the negative effect of aflatoxicosis on weights of some internal organs at 8 weeks (end of treatment period) is shown in Table 3. AF-diet group showed significantly higher relative weights of liver $(57.40 \%)$, kidney $(39.25 \%)$, spleen $(57.40 \%)$ and proventriculus $(21.62 \%)$ compared to the control group. While, relative weights of bursa of fabricus and thymus 
significantly decreased by AF (26.80 and 26.66\%) compared to the control group, respectively. Relative weights of heart and gizzard were not affected by AF. The increase in liver weight may be due to increasing fat accumulation in liver as a result of interference of aflatoxin with lipid metabolism (Smith and Hamilton, 1970; Qota, 2003 and Hassan, 2005). There were a significant $(\mathrm{P}<0.05)$ increase in relative weight of kidney, spleen and proventriculus for chicks fed AF-diet compared to the other treatments. These findings are in agreement with those obtained by Kubena et al. (1998) and Qota et al. (2005). Aflatoxin has been induce nutritional deficiency, resulting in depressed body weight, enlarged liver, spleen and proventriculus (Kubena et al., 1990a and Huff et al., 1992).

Table 3. Relative weight (\%) of some organs at the end of treatment and recovery periods as influenced by dietary AF and the treatment with humate levels and HSCAS

\begin{tabular}{|c|c|c|c|c|c|c|c|c|}
\hline Treatment & Liver & Spleen & Kidney & $\begin{array}{c}\text { Proventri- } \\
\text { culus }\end{array}$ & Gizzard & Heart & Bursa & Thymus \\
\hline \multicolumn{9}{|c|}{ At the end of treatment period ( $8 \mathrm{wk}$ of age) } \\
\hline Control & $2.236^{\mathrm{d}}$ & $0.216^{\mathrm{d}}$ & $1.076^{\mathrm{d}}$ & $0.370^{c}$ & 2.428 & 0.432 & $0.250^{\mathrm{a}}$ & $0.450^{\mathrm{a}}$ \\
\hline AF-diet & $3.516^{\mathrm{a}}$ & $0.340^{\mathrm{a}}$ & $1.490^{\mathrm{a}}$ & $0.450^{\mathrm{a}}$ & 2.409 & 0.450 & $0.183^{\mathrm{c}}$ & $0.330^{\mathrm{c}}$ \\
\hline $\begin{array}{l}\text { AF }+0.1 \% \\
\text { humate }\end{array}$ & $2.943^{\mathrm{b}}$ & $0.293^{\mathrm{b}}$ & $1.376^{\mathrm{ab}}$ & $0.406^{\mathrm{b}}$ & 2.479 & 0.450 & $0.216^{\mathrm{b}}$ & $0.373^{b c}$ \\
\hline $\begin{array}{l}\text { AF+0.25\% } \\
\text { humate }\end{array}$ & $2.500^{\mathrm{d}}$ & $0.254^{\mathrm{c}}$ & $1.250^{\mathrm{bc}}$ & $0.390^{\mathrm{bc}}$ & 2.413 & 0.460 & $0.230^{\mathrm{ab}}$ & $0.410^{\mathrm{ab}}$ \\
\hline $\begin{array}{l}\mathrm{AF}+0.40 \% \\
\text { humate }\end{array}$ & $2.460^{\mathrm{d}}$ & $0.240^{\text {cd }}$ & $1.170^{\mathrm{cd}}$ & $0.383^{b c}$ & 2.447 & 0.453 & $0.240^{\mathrm{ab}}$ & $0.420^{\mathrm{a}}$ \\
\hline $\begin{array}{l}\text { AF+0.50\% } \\
\text { HSCAS }\end{array}$ & $2.763^{b c}$ & $0.256^{\mathrm{c}}$ & $1.340^{\mathrm{b}}$ & $0.403^{\mathrm{b}}$ & 2.435 & 0.435 & $0.216^{\mathrm{b}}$ & $0.406^{\mathrm{ab}}$ \\
\hline SEM & 0.105 & 0.010 & 0.037 & 0.007 & 0.012 & 0.003 & 0.005 & 0.010 \\
\hline P-value & 0.0001 & 0.0001 & 0.0001 & 0.0001 & 0.694 & 0.276 & 0.001 & 0.001 \\
\hline \multicolumn{9}{|c|}{ At the end of recovery period ( 12 wk of age) } \\
\hline Control & $2.416^{\mathrm{c}}$ & $0.223^{\mathrm{c}}$ & $1.106^{\mathrm{c}}$ & 0.393 & 2.440 & 0.445 & 0.240 & $0.440^{\mathrm{a}}$ \\
\hline AF-diet & $3.496^{\mathrm{a}}$ & $0.300^{\mathrm{a}}$ & $1.346^{\mathrm{a}}$ & 0.416 & 2.410 & 0.463 & 0.200 & $0.370^{\mathrm{c}}$ \\
\hline $\begin{array}{l}\text { AF+0.1\% } \\
\text { humate }\end{array}$ & $2.910^{\mathrm{b}}$ & $0.280^{\mathrm{ab}}$ & $1.293^{\mathrm{ab}}$ & 0.406 & 2.478 & 0.443 & 0.217 & $0.396^{\mathrm{bc}}$ \\
\hline $\begin{array}{l}\mathrm{AF}+0.25 \% \\
\text { humate }\end{array}$ & $2.580^{\mathrm{bc}}$ & $0.246^{\mathrm{bc}}$ & $1.200^{\mathrm{abc}}$ & 0.393 & 2.469 & 0.446 & 0.226 & $0.420^{\mathrm{ab}}$ \\
\hline $\begin{array}{l}\mathrm{AF}+0.40 \% \\
\text { humate }\end{array}$ & $2.520^{\mathrm{c}}$ & $0.236^{\mathrm{c}}$ & $1.180^{\mathrm{bc}}$ & 0.396 & 2.450 & 0.450 & 0.233 & $0.426^{\mathrm{ab}}$ \\
\hline $\begin{array}{l}\text { AF+0.50\% } \\
\text { HSCAS }\end{array}$ & $2.723^{b c}$ & $0.250^{\mathrm{bc}}$ & $1.293^{\mathrm{ab}}$ & 0.410 & 2.441 & 0.450 & 0.220 & $0.416^{\mathrm{ab}}$ \\
\hline SEM & 0.095 & 0.007 & 0.025 & 0.004 & 0.0103 & 0.002 & 0.005 & 0.007 \\
\hline P-value & 0.0001 & 0.002 & 0.024 & 0.379 & 0.460 & 0.204 & 0.389 & 0.024 \\
\hline
\end{tabular}

Supplementation of humate levels or HSCAS decreased the severity of AF on all organs weights. Humate levels $(0.1,0.25$ and $0.40 \%)$ decreased the severity of aflatoxicosis on organs weight by $(44.53,79.00$ and $82.40 \%),(37.90,69.36$ and $80.64 \%),(28.56,57.15$ and $76.18 \%)$ and $(55.00,75.00$ and $83.77 \%)$, while HSCAS showed 58.59, 67.74, 35.72 and 58.72\% protection for liver, spleen, kidney and proventriculus, respectively, against $1 \mathrm{ppm}$ AFB1 at the end of treated period. These findings agreed with those obtained by Rensburg et al. (2006) who reported that 
oxihumate showed significant protective effects with respect to liver damage as indicated by an inhibition of liver enlargement. The results of Kubena et al. (1990a\&b), Huff et al. (1992) and Hassan (2000 and 2005) showed that adding HSCAS to aflatoxic diet alleviated the adverse effect of aflatoxicosis on liver damage. Decreasing bursa and thymus glands may be attributed to the depletion of follicular lymphocytes (Abd El-Hamid et al., 1992). Adding the studied additives decreased the severity of aflatoxin diets effects on the bursa and thymus weights. Protection of organs weight was observed by $0.1 \%$ humate $(49.25,35.82 \%), 0.25 \%$ humate $(70.15,66.70 \%), 0.40 \%$ humate $(85.07,75.02 \%)$ and HSCAS $(49.25$, $63.35 \%$ ) for bursa and thymus, respectively, against $1 \mathrm{ppm} \mathrm{AFB1/} \mathrm{kg}$ diet at the end of treatment period.

After 4 weeks of recovery period, it was noticed that relative weight of organs were more recovered for groups fed aflatoxic diets treated with humate levels and HSCAS compared to AF-diet. On the other hand, heart, gizzard and proventriculus weights were not statistically different among treatments and the control group (Table 3). This finding is in agreement with those of Hegazy and Edris (1991) and Qota et al. (2005) who found that after 4 weeks of recovery period, liver, spleen, bursa and thymus of chicks fed AF-diet were not completely recovered.

\section{Chemical Composition of Meat and Liver:}

Data in Table 4 show the chemical composition of meat and liver at $8^{\text {th }}$ and $12^{\text {th }}$ weeks of age. There was a significant decrease in protein content of meat of aflatoxin treated chicks, while insignificant decrease in fat content and significant $(\mathrm{P}<0.05)$ increase in moisture content were observed. Liver contents of AF-groups showed significantly $(\mathrm{P}<0.05)$ higher fat and lower protein and moisture contents compared to those of the control group at the $8^{\text {th }}$ week of treatment period. These results confirmed those obtained by Smith and Hamilton (1970); Inova et al. (1985) and Abd El-Hamid et al. (1995) who reported that aflatoxicosis impaired fat transport, which could be attributed to inhibited RNA synthesis, caused a marked increase in liver fat and as a result of that, its moisture was decreased, while protein content was decreased due to lowering the synthesis of protein in the liver (Abd El-Hamid et al. 1992). Adding humate or HSCAS decreased the severity of aflatoxicosis effect on meat and liver component, especially the groups fed aflatoxic diets treated with 0.25 and $0.40 \%$ humate. At the end of recovery period, the same alterations of treatments were shown only in contents of liver, while meat protein and moisture of groups fed detoxification additives showed similar value to the control group. Areif (1994) and Genedy et al. (1999) found that liver components did not fully recovered after 3 and 4 weeks of withdrawal from aflatoxicosis.

\section{Nutrients Digestibility:}

Addition of AF decreased the digestibility of dry matter, crude protein, crude fiber and ether extract compared to control diet (Table 5). Adding detoxification feed additives to aflatoxin supplemented diets improved digestibility coefficients of EE and $\mathrm{CP}$, while complete recovery was noticed in $\mathrm{DM}$ and $\mathrm{EE}$ digestibility when humate was supplemented at 0.25 or $0.40 \%$. These results agree with those of Compbell et al. (1983) who found that aflatoxin contaminated feed decrease the activities of several enzymes important in the digestion of carbohydrates, protein, lipids and nucleic acids in broiler chicks. Nelson et al. (1982) and Johri et al. (1996) found a decrease in amino acid and dry matter digestibility and energy utilization in 
broiler fed mycotoxins. Bolden and Jensen (1985) stated that nutritional deficiency induced by the aflatoxin could have disrupted the activity of the digestive enzymes and the absorption of essential nutrients.

Table 4. Chemical analysis (\%) of meat and liver at the end of treatment and recovery periods as influenced by dietary AF treated with humate levels and HSCAS

\begin{tabular}{|c|c|c|c|c|c|c|}
\hline \multirow{2}{*}{ Treatment } & \multicolumn{3}{|c|}{ Meat } & \multicolumn{3}{|c|}{ Liver } \\
\hline & Moisture & Protein & Fat & Moisture & Protein & Fat \\
\hline \multicolumn{7}{|c|}{ At the end of treatment period ( 8 wk of age) } \\
\hline Control & $74.00^{b}$ & $76.66^{\mathrm{a}}$ & 13.56 & $80.13^{\mathrm{a}}$ & $73.03^{\mathrm{a}}$ & $17.36^{\mathrm{c}}$ \\
\hline AF-diet & $79.00^{\mathrm{a}}$ & $71.70^{\mathrm{c}}$ & 13.00 & $75.30^{\mathrm{c}}$ & $65.33^{d}$ & $26.53^{\mathrm{a}}$ \\
\hline $\mathrm{AF}+0.1 \%$ humate & $76.83^{\mathrm{ab}}$ & $74.26^{\mathrm{b}}$ & 13.23 & $77.00^{\mathrm{b}}$ & $67.73^{\mathrm{cd}}$ & $23.16^{\mathrm{b}}$ \\
\hline $\mathrm{AF}+0.25 \%$ humate & $75.80^{\mathrm{ab}}$ & $75.06^{\mathrm{ab}}$ & 13.46 & $77.93^{\mathrm{b}}$ & $70.93^{\mathrm{ab}}$ & $20.86^{\mathrm{b}}$ \\
\hline $\mathrm{AF}+0.40 \%$ humate & $75.40^{\mathrm{b}}$ & $75.23^{\mathrm{ab}}$ & 13.53 & $78.23^{\mathrm{b}}$ & $71.00^{\mathrm{ab}}$ & $20.16^{\mathrm{bc}}$ \\
\hline $\mathrm{AF}+0.50 \% \mathrm{HSCAS}$ & $75.63^{\mathrm{ab}}$ & $75.40^{\mathrm{ab}}$ & 13.26 & $77.15^{\mathrm{bc}}$ & $69.43^{\mathrm{bc}}$ & $21.56^{\mathrm{b}}$ \\
\hline SEM & 0.519 & 0.429 & 0.110 & 0.379 & 0.669 & 0.760 \\
\hline P-value & 0.087 & 0.003 & 0.792 & 0.0001 & 0.001 & 0.001 \\
\hline \multicolumn{7}{|c|}{ At the end of recovery period ( $12 \mathrm{wk}$ of age) } \\
\hline Control & 74.10 & 77.06 & 14.10 & $79.16^{\mathrm{a}}$ & $73.63^{\mathrm{a}}$ & $18.00^{\mathrm{b}}$ \\
\hline AF-diet & 76.06 & 75.00 & 13.56 & $77.03^{\mathrm{b}}$ & $70.63^{c}$ & $22.63^{\mathrm{a}}$ \\
\hline AF+0.1\% humate & 75.60 & 76.10 & 13.80 & $77.60^{\mathrm{ab}}$ & $71.80^{\mathrm{bc}}$ & $20.86^{\mathrm{ab}}$ \\
\hline $\mathrm{AF}+0.25 \%$ humate & 75.00 & 76.00 & 14.10 & $78.00^{\mathrm{ab}}$ & $72.36^{\mathrm{b}}$ & $19.66^{\mathrm{b}}$ \\
\hline $\mathrm{AF}+0.40 \%$ humate & 74.90 & 76.26 & 13.66 & $77.93^{\mathrm{ab}}$ & $72.46^{\mathrm{b}}$ & $19.43^{\mathrm{b}}$ \\
\hline $\mathrm{AF}+0.50 \% \mathrm{HSCAS}$ & 75.20 & 76.15 & 13.66 & $76.96^{\mathrm{b}}$ & $71.76^{\mathrm{bc}}$ & $20.00^{\mathrm{ab}}$ \\
\hline SEM & 0.432 & 0.286 & 0.089 & 0.243 & 0.253 & 0.457 \\
\hline P-value & 0.542 & 0.893 & 0.375 & 0.068 & 0.002 & 0.050 \\
\hline
\end{tabular}

Table 5. Digestibility of nutrients (\%) at the end of treatment and recovery periods as influenced by dietary AF and treatment with humate levels and HSCAS

\begin{tabular}{lcccc}
\multicolumn{1}{c}{ Treatment } & DM & CP & EE & CF \\
\hline & At the end of treatment period (8 wk of age) & \\
\hline Control & $79.50^{\mathrm{a}}$ & $80.33^{\mathrm{a}}$ & $76.56^{\mathrm{a}}$ & 23.00 \\
AF-diet & $74.03^{\mathrm{c}}$ & $73.53^{\mathrm{b}}$ & $68.93^{\mathrm{c}}$ & 22.40 \\
AF+0.1\%humate & $76.26^{\mathrm{bc}}$ & $77.60^{\mathrm{a}}$ & $71.96^{\mathrm{b}}$ & 23.20 \\
AF+0.25\% humate & $77.26^{\mathrm{ab}}$ & $78.10^{\mathrm{a}}$ & $73.26^{\mathrm{b}}$ & 23.16 \\
AF+0.40\%humate & $77.86^{\mathrm{ab}}$ & $78.55^{\mathrm{a}}$ & $74.00^{\mathrm{b}}$ & 22.40 \\
AF+0.50\%HSCAS & $76.43^{\mathrm{bc}}$ & $77.70^{\mathrm{a}}$ & $72.93^{\mathrm{b}}$ & 23.20 \\
SEM & 0.504 & 0.584 & 0.622 & 0.379 \\
P-value & 0.015 & 0.004 & 0.001 & 0.982 \\
\hline & At the end of recovery period (12 wk of age) & \\
\hline Control & 79.26 & $80.00^{\mathrm{a}}$ & $76.00^{\mathrm{a}}$ & 22.00 \\
AF-diet & 76.13 & $76.93^{\mathrm{b}}$ & $70.73^{\mathrm{b}}$ & 22.03 \\
AF+0.1\%humate & 77.30 & $78.56^{\mathrm{ab}}$ & $74.30^{\mathrm{a}}$ & 22.46 \\
AF+0.25\%humate & 78.30 & $78.86^{\mathrm{a}}$ & $74.43^{\mathrm{a}}$ & 23.16 \\
AF+0.40\%humate & 78.03 & $79.26^{\mathrm{a}}$ & $74.53^{\mathrm{a}}$ & 22.06 \\
AF+0.50\%HSCAS & 77.80 & $78.33^{\mathrm{ab}}$ & $75.16^{\mathrm{a}}$ & 22.13 \\
SEM & 0.338 & 0.301 & 0.475 & 0.247 \\
P-value & 0.133 & 0.045 & 0.006 & 0.791 \\
\hline
\end{tabular}

\footnotetext{
${ }^{\mathrm{a}, \mathrm{b}}$ Means in the same column having different litters are significantly different $(\mathrm{P}<0.05)$
} 
After 4 weeks of recovery period, digestibility of $\mathrm{CP}$ and EE was still low in aflatoxin supplemented group. Meanwhile, group fed diets supplemented with humate $(0.25$ and $0.40 \%)$ or HSCAS showed nearly similar nutrient digestibility to that of the control group.

\section{Serum Constituents:}

Data in Table 6 demonstrate the effect of aflatoxin on serum constituents during treatment and recovery periods. The results clearly indicated that at the treatment period, total protein, albumin, total lipids, cholesterol and uric acid were reduced, but the serum enzymatic activity of AST and ALT increased in chicks fed AF-diet. Decreasing serum protein may be due to lower liver synthesis of albumin and globulin as a result of aflatoxicosis. These results are similar to those obtained by Abd El-Hamid et al. (1992), while decreasing serum total lipids may be due to the influence of aflatoxin with lipid metabolism (Hamilton et al., 1972). The low serum cholesterol concentration is most likely due to inhibition of cholesterol biosynthesis, with liver involvement, and perhaps a shift of concentration from the blood to the liver (Kubena et al., 1993). The serum enzymes data in the current results showed that the activity of AST, ALT and creatine kinase were increased by aflatoxin. These results supported the hepatoxic effect of aflatoxin and consequence hepatic cell damage and liver hypofunction (Varley et al., 1980). The kidney function data showed significant $(\mathrm{P}<0.05)$ decrease in uric acid and increase in creatine kinase.

Table 6. Some blood constituents at the end of treatment and recovery periods as influenced by dietary AF and treatment with humate levels and HSCAS

\begin{tabular}{|c|c|c|c|c|c|c|c|c|}
\hline Treatment & $\begin{array}{c}\text { TP } \\
\text { g/ } 100 \\
\text { ml }\end{array}$ & $\begin{array}{c}\text { Alb } \\
\text { g/ } 100 \\
\text { ml }\end{array}$ & $\begin{array}{l}\text { TL } \\
\text { g/l }\end{array}$ & $\begin{array}{c}\text { Chol } \\
\text { g/ } 100 \\
\text { ml }\end{array}$ & $\begin{array}{c}\text { AST } \\
\text { IU/ L }\end{array}$ & $\begin{array}{c}\text { ALT } \\
\text { IU } / \mathbf{L}\end{array}$ & $\underset{\mathrm{mg} / \mathrm{dl}}{\mathrm{UA}}$ & $\begin{array}{c}\mathrm{Cr} \\
\mathrm{mg} / \mathrm{dl}\end{array}$ \\
\hline \multicolumn{9}{|c|}{ At the end of treatment period ( 8 wk of age) } \\
\hline Control & $4.31^{\mathrm{a}}$ & $2.33^{\mathrm{a}}$ & $7.23^{\mathrm{a}}$ & $175.0^{\mathrm{a}}$ & $107.66^{\mathrm{d}}$ & $12.38^{\mathrm{c}}$ & $7.56^{\mathrm{a}}$ & $1.98^{\mathrm{c}}$ \\
\hline AF-diet & $2.21^{\mathrm{d}}$ & $1.53^{\mathrm{e}}$ & $5.08^{\mathrm{e}}$ & $126.66^{\mathrm{c}}$ & $167.66^{\mathrm{a}}$ & $19.83^{\mathrm{a}}$ & $5.33^{\mathrm{d}}$ & $2.53^{\mathrm{a}}$ \\
\hline $\mathrm{AF}+0.1 \%$ humate & $2.44^{\mathrm{d}}$ & $1.78^{\mathrm{d}}$ & $5.69^{d}$ & $149.00^{\mathrm{b}}$ & $132.00^{\mathrm{bc}}$ & $16.06^{\mathrm{b}}$ & $5.83^{\mathrm{cd}}$ & $2.45^{\mathrm{a}}$ \\
\hline $\mathrm{AF}+0.25 \%$ humate & $3.40^{\mathrm{b}}$ & $2.07^{\mathrm{bc}}$ & $6.25^{\mathrm{c}}$ & $161.33^{\mathrm{b}}$ & $134.33^{\mathrm{b}}$ & $14.33^{\mathrm{bc}}$ & $6.26^{\mathrm{bc}}$ & $2.14^{\mathrm{bc}}$ \\
\hline $\mathrm{AF}+0.40 \%$ humate & $3.62^{\mathrm{b}}$ & $2.23^{\mathrm{ab}}$ & $6.82^{\mathrm{b}}$ & $157.66^{\mathrm{b}}$ & $121.33^{\mathrm{c}}$ & $14.00^{\mathrm{bc}}$ & $6.73^{\mathrm{b}}$ & $2.07^{\mathrm{bc}}$ \\
\hline AF $+0.50 \%$ HSCAS & $3.05^{\mathrm{c}}$ & $2.03^{\mathrm{c}}$ & $6.44^{\mathrm{c}}$ & $155.66^{\mathrm{b}}$ & $129.66^{\mathrm{bc}}$ & $14.63^{\mathrm{bc}}$ & $6.16^{\mathrm{bc}}$ & $2.32^{\mathrm{ab}}$ \\
\hline SEM & 0.174 & 0.068 & 0.173 & 3.853 & 4.568 & 0.613 & 0.187 & 0.058 \\
\hline P-value & 0.0001 & 0.0001 & 0.0001 & 0.0001 & 0.0001 & 0.0001 & 0.0001 & 0.009 \\
\hline \multicolumn{9}{|c|}{ At the end of recovery period (12 wk of age) } \\
\hline Control & $4.40^{\mathrm{a}}$ & $2.42^{\mathrm{a}}$ & $7.15^{\mathrm{a}}$ & $177.33^{\mathrm{a}}$ & $109.33^{\mathrm{d}}$ & $12.58^{\mathrm{c}}$ & $7.63^{\mathrm{a}}$ & $2.02^{c}$ \\
\hline AF-diet & $3.11^{\mathrm{e}}$ & $2.07^{\mathrm{c}}$ & $5.93^{\mathrm{d}}$ & $139.00^{\mathrm{d}}$ & $146.00^{\mathrm{a}}$ & $18.50^{\mathrm{a}}$ & $5.70^{\mathrm{c}}$ & $2.40^{\mathrm{a}}$ \\
\hline AF $+0.1 \%$ humate & $3.38^{\mathrm{de}}$ & $2.18^{\mathrm{bc}}$ & $5.99^{d}$ & $157.00^{\mathrm{c}}$ & $131.00^{\mathrm{b}}$ & $15.80^{\mathrm{b}}$ & $6.16^{\mathrm{bc}}$ & $2.32^{\mathrm{ab}}$ \\
\hline $\mathrm{AF}+0.25 \%$ humate & $3.82^{\mathrm{bc}}$ & $2.27^{\mathrm{b}}$ & $6.48^{\mathrm{c}}$ & $167.33^{\mathrm{b}}$ & $132.66^{\mathrm{b}}$ & $14.16^{\mathrm{bc}}$ & $6.60^{\mathrm{b}}$ & $2.11^{\mathrm{c}}$ \\
\hline $\mathrm{AF}+0.40 \%$ humate & $3.93^{\mathrm{b}}$ & $2.32^{\mathrm{ab}}$ & $7.05^{\mathrm{ab}}$ & $164.66^{\mathrm{bc}}$ & $119.33^{c}$ & $14.06^{\mathrm{bc}}$ & $6.76^{\mathrm{b}}$ & $2.02^{\mathrm{c}}$ \\
\hline AF $+0.50 \%$ HSCAS & $3.62^{\mathrm{cd}}$ & $2.19^{\mathrm{bc}}$ & $6.78^{b c}$ & $164.00^{\mathrm{bc}}$ & $129.00^{\mathrm{b}}$ & $14.30^{\mathrm{bc}}$ & $6.70^{\mathrm{b}}$ & $2.19^{\mathrm{bc}}$ \\
\hline SEM & 0.104 & 0.031 & 0.121 & 3.00 & 2.958 & 0.485 & 0.167 & 0.040 \\
\hline P-value & 0.0001 & 0.002 & 0.0001 & 0.0001 & 0.0001 & 0.0001 & 0.003 & 0.002 \\
\hline
\end{tabular}

Elevation of creatine kinase in chickens fed aflatoxin supplemented diet is probably a result of muscle trauma (Tietz, 1976). While, the effect of AF on serum uric acid was similar to the effect on serum protein level, this result agreed with those 
obtained by Reddy et al. (1984) who found a decrease in uric acid percentage during aflatoxicosis.

Feed additives supplementation alleviated the adverse effect of aflatoxicosis on serum constituents during the treatment period. The best results were recorded for group fed diet supplemented with 0.25 or $0.40 \%$ humate, which provided more protection than HSCAS (Table 6). This could explain superior performance of these groups. These results are in agreement with those of Rensburg et al. (2006) who found that total protein, albumin and creatine phosphokinase were returned to control value, when oxihumate was used with aflatoxin exposed chickens. Addition of HSCAS to the diet containing AF significantly $(\mathrm{P}<0.05)$ decreased the negative effect of AF on the serum constituents (Genedy et al., 1999; Hassan, 2000 and Qota et al., 2005).

At the end of recovery period, all groups showed similar serum constituents to the control group except for AST, ALT and creatine kinase of chicks fed AF-diet. These results are in agreement with those reported by Hassan (2000\&2005).

\section{Aflatoxin Residues:}

$\mathrm{AFB}_{1}$ residue was found in liver and meat tissues of chicks fed aflatoxin diets without or with studied additives at the end of treatment period, while the control group showed no residues of $\mathrm{AFB}_{1}$ in their tissues (Table 7). These results confirmed those obtained by Trucksess et al. (1983); Sova et al. (1984) and Hegazy and Edris (1991) who found that chickens fed aflatoxin diets accumulate residues of $\mathrm{AFB}_{1}$ in their meat and liver tissues. Concentrations of $\mathrm{AFB}_{1}$ residues were higher in liver than in meat of all aflatoxin groups at the end of treatment period (Table 7). These results agree with those obtained by Abd El-Hamid at al. (1995); Abo Sree et al. (1999) and Qota et al. (2005) who found that liver accumulate more aflatoxin than meats of chicks fed AF- supplemented diets. Adding studied additives to AF-diet decreased residues of $\mathrm{AFB}_{1}$ in the liver and meat with $0.1 \%$ humate by $(20.83,21.43$ $\%$, with $0.25 \%$ humate by $(56.69,35.21 \%)$, with $0.40 \%$ humate by $(54.31,35.71$ $\%)$ and with HSCAS by $(50.00,33.78 \%)$, respectively, compared to aflatoxin containing diet without additives (Table 7). The efficiency values of humate at levels $(0.25$ and $0.40 \%)$ were higher than HSCAS for diminished aflatoxicosis and decreased $\mathrm{AFB}_{1}$ residue in liver and meat at the end of treatment and recovery periods. Concentrations of $\mathrm{AFB}_{1}$ residues in the liver and meat were decreased by 53$71 \%$ after 4 weeks recovery period compared to that of the treatment period (Table 7). Aflatoxin was absent from tissues or presented with low concentrations in breast and leg and removed in two to four weeks after withdrawing the toxic diet ( ElShaarawi et al., 1983 and Mocco et al., 1988).

In vitro experiment showed that oxihumate mixed with poultry feed absorbed $\mathrm{AFB}_{1}$ with the same efficacy in buffer alone, at $\mathrm{pH}_{3}$ and $\mathrm{pH}_{7}$, suggesting that oxihumate does not bind feed molecules. In this experiment, oxihumte bound $92.0 \%$ of the $\mathrm{AFB}_{1}$ at $\mathrm{pH}_{3}$ and $82.2 \%$ at $\mathrm{pH}_{7}$, whereas $92.9 \%$ and $87.5 \%$ of the $\mathrm{AFB}_{1}$ were bound at $\mathrm{pH}_{3}$ and $\mathrm{pH}_{7}$, respectively, in the presence of both oxihumate and poultry feed. All oxihumate particles mixed into mycotoxin-contaminated feed should, therefore, be available for the formation of oxihumate-mycotoxin complex. The complex may, however, not be very stable, as it was ruptured to a high degree in the presence of acetonitrile (61\%) and acetone (75\%), but not chloroform $(3 \%)$. The failure of chloroform to rupture the complex may be attributed to the high capacity of 
oxihumate to hold water in and around its structure with a consequential gel formation, thus preventing the hydrophobic chloroform from penetrating the water layer. The aflatoxin in association with oxihumate is water-insoluble and the chloroform can, therefore, not reach the complexes (Rensburg et al., 2006).

Table 7. Effect of humate levels and hydrated sodium calcium aluminosilicate (HSCAS) on the $\mathrm{AFB}_{1}$ residues (ng/g.) in liver and meat of birds fed diet containing 1 ppm AFB1

\begin{tabular}{|c|c|c|c|c|}
\hline \multirow[t]{2}{*}{ Treatment } & \multicolumn{2}{|c|}{ Treatment period } & \multicolumn{2}{|c|}{ Recovery period } \\
\hline & Liver & Muscles & Liver & Muscles \\
\hline Control & $0.00 *$ & 0.00 & 0.00 & 0.00 \\
\hline AF-diet & $80.00^{\mathrm{a}}$ & $14.00^{\mathrm{a}}$ & $28.00^{\mathrm{a}}$ & 6.47 \\
\hline $\mathrm{AF}+0.1 \%$ humate & $63.33^{\mathrm{b}}$ & $11.00^{\mathrm{ab}}$ & $18.00^{\mathrm{b}}$ & 3.78 \\
\hline $\mathrm{AF}+0.25 \%$ humate & $34.65^{\mathrm{c}}$ & $9.07^{\mathrm{b}}$ & $16.00^{\mathrm{b}}$ & 2.55 \\
\hline $\mathrm{AF}+0.40 \%$ humate & $36.55^{\mathrm{c}}$ & $9.00^{\mathrm{b}}$ & $12.55^{\mathrm{b}}$ & 3.00 \\
\hline $\mathrm{AF}+0.50 \% \mathrm{HSCAS}$ & $40.00^{\mathrm{c}}$ & $9.26^{\mathrm{b}}$ & $16.30^{\mathrm{b}}$ & 3.28 \\
\hline SEM & 5.051 & 0.665 & 1.554 & 0.526 \\
\hline P-value & 0.0001 & 0.046 & 0.001 & 0.109 \\
\hline
\end{tabular}

* No detecting of aflatoxin $\mathrm{B}_{1}$

a, b, c, d Means in the same column having different litter are significantly different $(\mathrm{P}<0.05)$

The in vitro experiments carried out with radio labeled aflatoxin B1 (Phillips et al., 1988) demonstrated that of 38 different absorbents tested (a variety of aluminas, zeolites, silicas, phyllosilicates and chemically modified phyllosilicates), HSCAS was the best aflatoxin $\mathrm{B}_{1}$-absorbing compound as it was able to form the most stable complex with this mycotoxin (with adsorption of more than $8 \%$ of aflatoxin $\mathrm{B}_{1}$ present in the medium). The complex was also demonstrated to be stable in water at $\mathrm{pH}_{2,7}$ and 10 and at temperatures of 25 and $37^{\circ} \mathrm{C}$. The stability of the HSCAS-aflatoxin $\mathrm{B}_{1}$ sorption complex was evaluated by extraction with an elutropic series of solvents. As less than $10 \%$ of aflatoxin $\mathrm{B}_{1}$ was extracted, they suggested that the mechanism implicated in this process could be chemisorption with the formation of strong bonds between the molecules, but later on, a more specific mechanisms was proposed (Phillips et al., 1990b and Sarr et al., 1990). This mechanism was the formation of a complex by the $\beta$-carbonyl system of the aflatoxin with uncoordinated edge site aluminum ions HSCAS.

In the present study, results indicated that adding HSCAS to chicks diet as a decontamination method to sorb aflatoxin selectively during the digestive process, was less effective compared to humate $(0.25$ and $0.40 \%)$. Oxihumate showed a high affinity for $\mathrm{AFB}_{1}$, zearalenone, ochratoxin $\mathrm{A}$, ergosine, ergotamine, ergocornine, ergocryptine and ergocristine, but did not bind to vomitoxin. The binding capacity of Mycosorb (HSCAS) to $\mathrm{AFB}_{1}$ at $\mathrm{PH}_{3}$ proved to be considerably less than that of oxihumate (Rensburg et al., 2006).

These results clearly demonstrated that the growth performance (BW, FI and FCR), weights of some internal organs, blood constituents, nutrients digestibility and immune response of local chicks were negatively affected by feeding $\mathrm{AFB}_{1}$ for 8 weeks. Meanwhile, addition of humate levels and HSCAS to AF-containing diet significantly $(\mathrm{P}<0.05)$ recovered and ameliorated the adverse effects of $\mathrm{AF}$ on performance especially, humate at 0.25 and $0.40 \%$ which resulted in the best mean. 
These positive effects may have a safe and practical decontamination procedure and contribute to a solution of AF problem in poultry.

\section{REFERENCES}

AOAC, 2000. Official Methods of Analysis. 17 $7^{\text {th }}$ ed. Assoc. off. Anal. Chem., Arlington, VA.

Abd El-Hamid H.S., A.G.R. Shakshouk, M. Korshom, E.M. El-Manakly and A.B.A. Bekhiet, 1992. Effect of aflatoxin on broiler chickens. Egypt. Poult. Sci., 12(11): 443.

Abd El-Hamid A.M., H.S.M. Ariel, F. El-Keraby and T.M. Porra, 1995. Effect of some dietary supplements to aflatoxin diets of chicks. II. On the tissues analysis. J. Agric. Sci., Mansoura Univ., 20(7): 3227.

Abo-Sree Y.H., S.G.K. Genedy, N.M. El-Nagar and E.M.A. Qota, 1999. Effect of feeding aflatoxin diets with and without decontaminating agents on its residues in tissues, reproductivity and semen quality of local chicken strains. Egypt. Poult. Sci., 19: 379.

Alvarez- Puebla R.A., C. Valenzuela- Calahorro and J.J. Garrido, 2004 . Modelling the absorption and precipitation processes of $\mathrm{Cu}$ ( II ) on humin. Journal of Colloid and Interface Science, 277, 56 -61 .

Areif, H.S.M., 1994. Physionutritional studies on the poultry mycotoxicosis. Ph.D. Thesis, Fac. of Agric., Mansoura Univ.

Bolden S. and L. Jensen, 1985. The effect of marginal levels of calcium, fish meal, torulas yeast and alfalfa meal on feed intake, hepatic lipid accumulation, plasma estradiol and egg shell quality among laying hens. Poult. Sci., 64: 937-946.

Compbell M.L., J.D. May, W.E. Huff and J.A. Doerr, 1983. Evaluation of immunity of young broiler chicks during simultaneous aflatoxicosis and ochratoxicosis. Poult. Sci., 62: 2138.

Cozzi R., M. Nicolai, P. Perticone, R. De Salvia and F. Spuntarelli, 1993. Desmutagenic activity of natural humic acids: Inhibition of mitomycin $\mathrm{C}$ and maleic hydrazide mutagenicity. Mutat. Res., 299: 37-44.

Doyle, M.P., R.S. Applebaum, R.E. Brackett and E.H. Marth, 1982. Physical, chemical and biological degradation of mycotoxins in foods and agricultural commodities. J. Food Prot., 45: 946-971.

Duncan D. B., 1955. Multiple range and multiple F. tests. Biometrics, 11:1-42.

Edrington T.S., L.F. Kubena, R.B. Harvey, and G.E. Rottinghaus, 1997. Influence of a superactived charcoal on the toxic effects of aflatoxin or T-2 in growing broilers. Poult. Sci., 76: 1205.

Egyptian Feed Composition Tables for Animal and Poultry Feedstuffs, 2001. Technical bulletin No. 1. Central Lab. for Feed and Food, Ministry of Agric., Egypt.

El-Shaarawi G., R.I. Mashaly, S.A. El-Dean and M.A Kosba, 1983. Effect of aflatoxin treatment on body and organ weights and on aflatoxin residue in tissue on two different strains of broiler chickens. Abstracts: International Mycotoxin Conference, National Research Center, March 19-24, Cairo, Egypt.

Fein J.B., J. Boily, K. Guclu and E. Kaulbach, 1999. Experimental study of humic acid adsorption onto bacteria and Aloxide mineral surfaces. Chem. Geol., 162: $33-45$. 
Genedy S.G.K., N.M. El-Nagar, N.S. Isshak and E.M.A. Qota, 1999. Effect of aflatoxins decontaminating agents on performance, blood constituents and some tissues of local poultry strains. Egypt. Poult. Sci., 19(II): 351.

Ghazalah A.A., S.H. El-Samra, S.M. Higazy and Z.M. Abdo, 1995. Effect of interaction between vitamin B1, fat and mycotoxins on the performance of broiler chicks. Proc. $5^{\text {th }}$ Sci. Conf. Anim. Nutr., Vol. 1: 287, Ismailia 12-13 December.

Hamilton P.B., H.T. Tung, J.R. Harris, J.H. Gainer and W.E. Donaldson, 1972. Effect of dietary fat on aflatoxicosis in turkey. Poult. Sci., 51: 165.

Hassan R.A., 2000. Studies on the efeect of certain feed-additives on the performance of broiler and layers fed aflatoxicated feed. Ph.D. Thesis, Fac. of Agric. Kafr ElSheikh, Tanta Univ.

Hassan R.A., 2005. Capability of mannan-oligosaccharide (Bio-Mos ${ }^{\circledR}$ ), organic selenium and hydrated sodium calcium aluminosilicate to detoxify aflatoxicosis for growing local chickens. 1- performance, some internal organs and blood constituents. Proc. $2^{\text {nd }}$ Conf. Anim. Prod. Res. Inst., Sakha 27-29 Sep. 2005: 559574.

Hegazy S.M. and A.B.M. Edris, 1991. Aflatoxin deposition and clearance from tissues of broiler chickens fed a contaminated diet. Zagazig Vet. J., 19(4): 958.

Huff W.E., L.F. Kubena, R.B. Harvey and T.D. Phillips, 1992. Efficacy of hydrated sodium calcium aluminosilicate to reduce the individual and combined toxicity of aflatoxin and ochratoxin A. Poult. Sc., 71: 64.

Huwig A., S. Freimund, O. Kappli and H. Dutler, 2001. Mycotoxin detoxification of animal feed by different adsorbents. Toxical Lett., 122: 179-188.

Inova I., R. Petkov and G. Monov, 1985. Chemical composition of meat from broiler given feed containing aflatoxin B. Veterinarnomeditsins: Nouki, 25: 51 (Bulgaria).

Jakobsen, P.E., S.G. Kirston and S.H. Nielson, 1960. Digestibility trials with poultry. 322. Bereting Fraforsgs Laboratoriet Udgivet of Stants. Husdybugsud ValyKaben Haven.

Johri T.S., J. Verma and A.R. Shrivastav, 1996. The individual and combined effects of aflatoxin and ochratoxin on protein quality and metabolizability of energy in broilers. Proceedings of the $20^{\text {th }}$ World's Poultry Congress, New Delhi, 4: 275.

Kollist-Sugar K., T. Nielsen, C. Gron, P.E. Hansen, C. Helweg, K.E. Jonassen, O. Jorgensen and U. Kirso, 2001. Sorpsion of polycyclic aromatic compounds to humic and fulvic acid HPLC column materials. J, Environ. Qual., 30: 526-537.

Kubena L.F., R.B. Harvey, R.H. Bailey, S.A. Buckley, and G.E. Rottinghous, 1998. Effects of hydrated sodium calcium aluminosilicate (T-Bind TM) on mycotoxicosis in young broiler chickens. Poult. Sci., 77: 1502-1509.

Kubena L., R.B. Harvey, W.E. Huff and D.E. Carrier, 1990a. Efficacy of a hydrated sodium calcium aluminosilicate to reduce the toxicity of aflatoxin and T-2 toxin. Poult. Sci., 69: 1078.

Kubena L., R.B. Harvey, T.D. Phillips, D.E. Carrier and W.E. Huff, 1990b. Diminution of aflatoxicosis in growing chickens by the dietary addition of a hydrate sodium calcium aluminosilicate. Poult. Sci., 69: 727.

Kubena L., R.B. Harvey, T.D. Phillips, and B.A. Clement, 1993. Efficacy of hydrated sodium calcium aluminosilicate on afltoxicosis in broiler chicks. Poult. Sci., 72: 651 . 
Kubena L., R.B. Harvey, T.D. Phillips and B.A. Clement, 1992. Efficacy of several sorbent materials for protection against aflatoxicosis in broiler chicken. Poult. Sci., 71: 47.

Kuhnert M., V. Fusch and S. Golbs, 1982a . Pharmacological and toxicological investigation of humic acids intended for oral administration for treatment of gastric and intestinal diseases in farm animals . In : Proceedings of International Symposium, Minks, $232-243$.

Kuhnert M., V. Fusch and S. Golbs, 1982b . Chemical properties and particularly pharmacological and toxicological characteristics of humic acids . Archiv fur experimentelle Veterinarmedizin, 36, $169-177$.

Madronova L., J. Kozler, J. Cezikova, J. Novak and P. Jonos, 2001. Humic acids from coal of the North-Bohemia coal field. III. Metal-binding properties of humic acids-measurements in acolumn arrangement. React. Func. Polym., 47: 119-123.

Marquardt R.R. 1996. Effects of molds and their toxins on livestock performance: A Western Candian Perspective. Anim. Feed Sci. Technol., 58: 77-89.

Miazzo R., C.A. Rosa, E.C. Carvalho, C. Magnol, S.M. Chiacchiera, G. Palacio, M. Saenz, A. Kikato, E. Asaldells and A. Dalcero, 2000. Efficacy of synthetic zoelite to reduce the toxicity of aflatoxin in broiler chicks. Poult. Sci., 79: 1.

Mocco C., M. Maraglia, R. Onor, C. Brera, A. Mantovani, A. Iappolo and D. Stasalla, 1988. Long term administration of few doses of mycotoxin to poultry. 1Residues of aflatoxin B1 and its metabolites in broilers and laying hens. FoodAddit., 2: 303.

Nabney J. and B.F. Nesbitt, 1965. A spectrophotometric method of determining the aflatoxin. Anaslyst, 90: 155-160.

Nanny M.A. and J.P. Maza, 2001. Noncovalent interactions between monoaromatic compounds and dissolved humic acid: A deuterium NMRT1 relaxation study. Environ. Sci. Technol., 35: 379-384.

Negre M., H.R. Schulten, M. Gennari and D. Vindrola, 2001. Interaction of imidazolinone herbicides with soil humic acids. Experimental results and molecular modeling. J. Environ. Sci. Health B., 36: 107-125.

Nelson T.S., Z.B. Johnson, L.K. Kirby and J.N. Beasley, 1982. Digestion of dry matter, amino acids and energy utilization by chicks fed modulated corn containing mycotoxins. Poult. Sci., 61: 534-585.

Oguz H. and A. Kurtoglu, 2000. Effect of clinoptiolite on fattening performance of broiler chickens during experimental aflatoxicosis. Bri. Poult. Sci., 41: 512.

Oratatli M. and H. Oguz, 2001. Ameliorative effects of dietary clinoptiolite on pathological changes in broiler chickens during aflatoxicosis. Researcher in Veterinary Science, 71: 59.

Osborn, D.J. and P.B. Hamilton, 1981. Steatorrhea during aflatoxicosis in chickens. Poult. Sci., 60: 1398.

Parlat S.S., M. Ozcan and H. Oguz, 2001. Biological suppression of aflatoxicosis in Japanes quail (Coturnix Coturnix Japonica) during experimental aflatoxicosis. Brit. Poult. Sci., 40: 495-500.

Phillips T.D., L. Ku, R.B. Harvey, D.S. Taylor and N.D. Heidelbugh, 1988. Hydrated sodium calcium aluminosilicate. A high affinity sorbent of aflatoxin. Poult. Sci., 67: 243 . 
Qota E.M.A., 2003. Hydrated sodium calcium aluminosilicate effects on some mineral and vitamin status during aflatoxicosis in growing turkey. J. Agric. Sci. Mansoura Univ., 28(3): 1729.

Qota, E.M.A., M.N. Ali, R.A. Hassan, and M.K. Abo El-Maged, 2005. Detoxification of aflatoxin cominated local chicken diets using aluminosilicate sodium sulphate and peroxidase enzyme. $3^{\text {rd }}$ International Poultry Conference, 47 Apr. Hurghada, Egypt.

Ramos A.J. and E. Hernandez, 1996a. In vitro aflatoxin adsorption by maens of a montmorillonite silicate. A study of adsorption isotherms. Anim. Feed Sci. Technol., 62: 263-269.

Ramos A.J., J. Fink-Gremmels and E. Hernandez, 1996a. Prevention of toxic effects of mycotxins by means of nonnutritive absorbent compounds. J. Food Prot., 59: 631-641.

Ramos A.J., E. Hernandez, M. Pla-Delfina, and M. Merino, 1996b. Intestinal absorption of Zearalenone and in vitro study of non-nutritive sorbent materials. Int. J. Pharm., 128: 129-137.

Reddy D.N., P.V. Rao, V.R. Reddy and B. Yadgiri, 1984. Effect of selected levels of dietary aflatoxin on the performance of broiler chickens. Indian J. Anim. Sci., 54: 68.

Rensburg C., C.E.J. Rensburg, J.B.J Ryssen, N.H. Casey and G.E. Rottinghaus, 2006. In vitro and in vivo assessment of humic acid as an aflatoxin Binder in broiler chickens. Poult. Sci., 85: 1576-1583.

SAS Institute, 1998. SAS/ STAT User's Guide: Statistics Version 6, Cary, NC, SAS Institute.

Santos A., I.C. Bellin, P.P. Corbi, A. Cuin , A.H. Rosa, M.O. Rezende, J.C. Rocha and P. Melnikov, 2004 . Competition between humic substances and alph- amino acid by metal species. Journal of the Brazilian Chemical Society, 15, $437-440$.

Scheideler A.E., 1993. Effect of various types of aluminosilicates and aflatoxin B1 on aflatoxin toxicity, chicks performance and mineral status. Poult. Sci., 72: 282.

Shotwell O.L., C.W. Hesseltine, R.D. Stubbefield and W.G. Sorenson, 1966. Production of aflatoxin on rice. Appl. Microbiol., 14: 425.

Smith J.W. and P.B. Hamilton, 1970. Aflatoxicosis in broiler chicken. Poult. Sci., 49: 207.

Sova Z., D. Trefney, L. Fukel, L. Tlusta, J. Kalous and J. Prosek, 1984. Effect of low concentration of aflatoxin B1 in the diet of hens on the formulation of tissues. Biol. Chem. Vet., 26: 331.

Tietz N. 1976. Fundamentals of clinical chemistry. W. D. Sanders, Philadelphia, PA.

Trucksess M.W., L. Stoloff, K. Young, D.R. Wyatt and B.L. Miller, 1983. Aflatoxical and aflatoxin B1 and M1 in eggs and tissues of laying hens consuming aflatoxin-contaminated feed. Poult. Sci., 62: 2176.

Varley H., A.H. Gowenlock and M. Bell, 1980. Practical clinical biochemistry, $5^{\text {th }}$ Ed., pp. 215-217, William Heineman Medical Books, London.

West S., R.D. Wyatt, and P.B. Hamilton, 1973. Improved yield of aflatoxin by incremental increases in temperature. Appl. Microbiol., 25: 1018.

Wiseman H.G., W.C. Jacobsn and W.E. Harmey, 1967. Note of removal of pigments from chloroform extracts of aflatoxin cultures with copper carbonate. J. Assoc. Agric. Chem., 50: 982. 


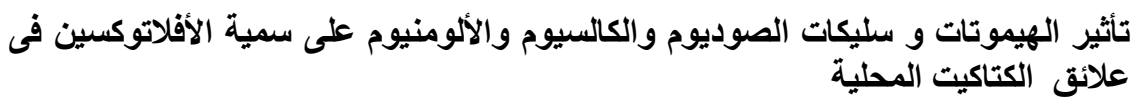

رضا على حسن'، و ائل عوض مرسى'، نادية لطفى رضوان'، يحى زكريا عيد'

ا ـ معطه بحوث الإنتاج الحيوانس، مركز البحوث الزراعية، وزارة الزراعة، مصر، r ـ قسم انتاج الدواجن، كلية زراعة كفرالثيخ، جامعة كفرالثبيخ

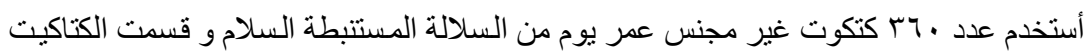

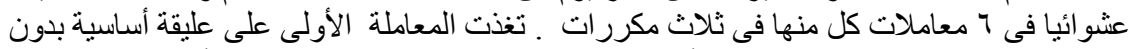

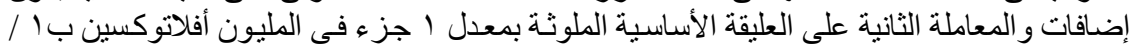

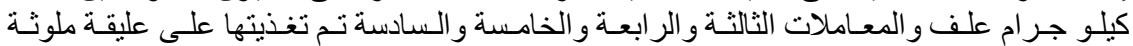

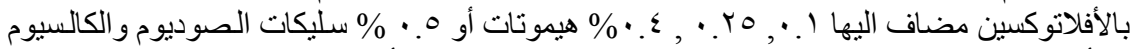

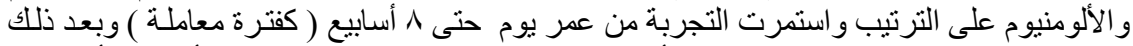

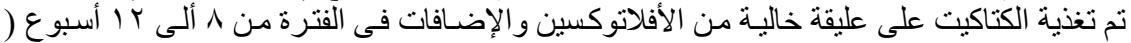

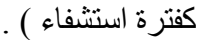

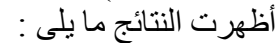

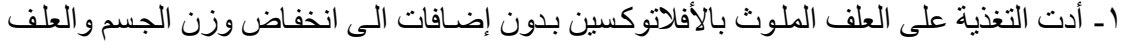

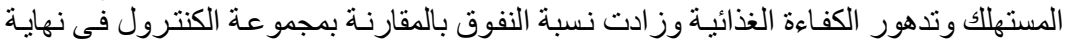

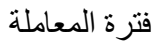

r ـ ز اد الوزن النسبى لكل من الكبد , الكلية , الطحال و المعدة الغديـة معنويـا فى الكتاكيت التىى تغذت

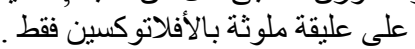

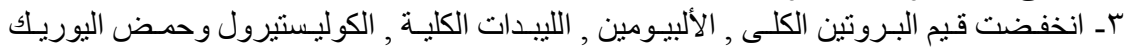

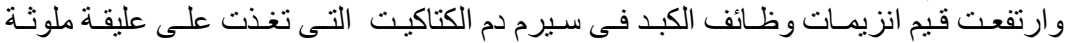

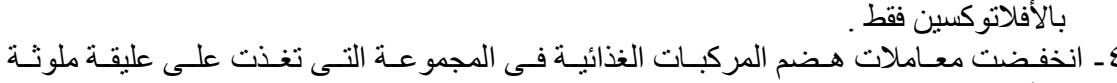
بالأفلاتو كسين فقط.

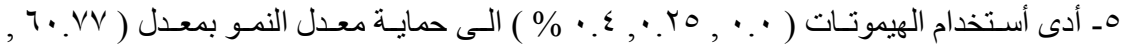

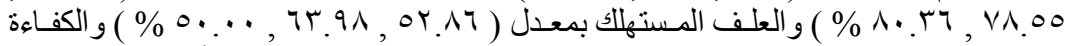

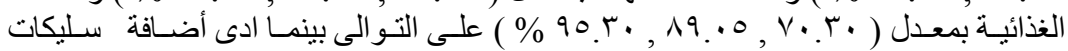

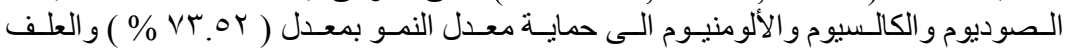

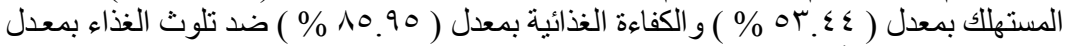

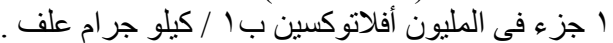

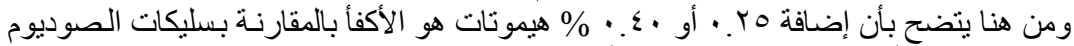

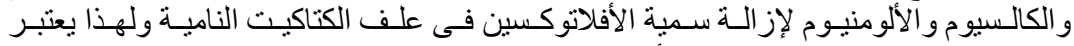

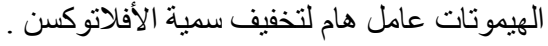

